\title{
Development of Students 'Sheet Activities Through Inquiry Models in Various Themes of Class IV Students' Basic Schools
}

\author{
Denny Irawan H.* Arwin Surbakti M. Thoha B.S. Jaya Alben Ambarita \\ FKIP Universitas Lampung, Jl. Prof. Dr. Soemantri Brojonegoro No. 1 Bandar Lampung
}

\begin{abstract}
Abstrak
Penelitian ini bertujuan untuk mengembangkan lembar kerja siswa, dan mengetahui perbedaan efektivitas LKS berbasis tematik melalui model Inquiry bagi siswa kelas IV Sekolah Dasar Negeri I Pinang Jaya. Jenis penelitian adalah penelitian dan pengembangan (R\&D) merujuk teori Borg \& Gall. Populasi penelitian adalah seluruh siswa kelas IV SDN Kecamatan Sekampung Gugus Ahmad Yani dan sampel 54 siswa yang diperoleh dengan teknik multistage random sampling adalah siswa kelas IV SDN I Klopo Mulyo. Alat pengumpulan data menggunakan tes untuk hasil belajar dan instrumen pengamatan. Teknik analisis data dilakukan dengan analisis kuantitatif untuk pengembangan produk yaitu uji efektivitas digunakan N-gain dan uji t. Hasil penelitian menunjukkan bahwa LKS yang dikembangkan layak digunakan dan efektif meningkatkan hasil belajar siswa.
\end{abstract}

Kata kunci : lembar kerja siswa, inquiry, hasil belajar .

\begin{abstract}
This study aims to develop student worksheets, and to know the effectiveness of thematic based LKS through Inquiry model for fourth grade students of Elementary School I Pinang Jaya. This type of research is research and development (R \& D) which refers to Borg \& Gall's theory. The study population was all grade IV students of SDN Sekampung Gugus Ahmad Yani District and a sample of 54 students obtained by multistage random sampling technique were grade IV students of SDN I Klopo Mulyo. Data collection techniques use learning and observation tests. Data analysis technique is done through quantitative analysis for product development that is effectiveness test used $\mathrm{N}$-gain and $\mathrm{t}$ test. The results of this study indicate that the developed LKS feasible to be used and effective through experts from material experts and media experts in improving student learning outcomes.
\end{abstract}

Keywords: student, student worksheet, inquiry, learning result.

DOI: $10.7176 / \mathrm{JEP} / 11-8-10$

Publication date:March $31^{\text {st }} 2020$

\section{INTRODUCTION}

Education issues are interesting to be discussed in many forums, both formally and informally, related to its policy, implementation, and up to the impacts of that policy. Education process begin from family level continued to formal level at school, starts from elementary education to higher education. The educational issue that got a lot of attentionisrelated to the process of establishing quality learners, which in this case, the quality of learning process and the competence of educators as an implementer of learning in the classroom.

Many factors that can be used to improves the learningquality, including selection and usage of teaching materials. Learning devices that meet well-presented curriculum bills will be able to motivate students to participate actively and creatively, able to solve problems in their life by using the concept of knowledge that had been learned, able to understand the lesson well, andable to self-organizing their knowledges. The goal isstudents are able to find a concept of the study materials, not only give answers to the problems that founded. Learning activities can not be separated from the involvement of teaching materials. Everything that teachers use to convey a lesson can be classified as teaching materials. Teaching materials provide directionsof the learning process to be implemented.

Learning materials are an important partin the implementation of education at school. Through teaching materials, teachers will be easier in teaching process and students will be more helped and easier to learn. Teaching materials can be made in various forms dependingon the needs and the characteristics of presented teaching materials.

One of the teaching materials is the Student Work-Sheet (Lembar Kegiatan Siswa/ LKS). Student Worksheetisa collection of sheets that contain brief materials, student activities and tasks that must be completed by students according to their basic competencies.

The observation results at Elementary School 1 of Pinang Jaya showedthat the scores of Natural Science examination is the most apprehensivescore compared to other examinations. From the results of first theme of natural science daily exam scores, there are 18 students who does not reachKKM (minimum passing score)inclass IV Aorequal to $70,83 \%$ fromthe total of 26 students, andinclassIV B,there are 19 studentswho does not reach KKMfrom the total of 28 students.

Based on the results of questionnaire distributed by researcher to teachers of class IV in 3 (three) different 
schools,it is concluded that the learning process that hasbeen done so far is still teacher-dominated and use only one Student Worksheet per two students. The student worksheetsthat were used is a conventional worksheets which is less encouraging for students to be active in learning activities. Therefore, it is necessary to provide teaching materials that are inviting students to actively participate in the process of discovery or investigationin a scientific method,so students are able to discover their own knowledges and skills. A suitable teaching material isa material that can facilitate students to think critically, creatively and independentlywhich will lead students to discover their knowledges and skills, so the learning process are run using a student-centered approach.

Based on the observations that have been described above, there are several problems arise, such as : The students' skills in natural science subject are still low, the learning process is still dominated by teachers, the teaching materials are an important part of the education performance in schools, the students are not challenged to link their knowledgeswith learning materials so that students are less motivated to explore their own knowledge, learning should be organized actively, inspiratively, fun and challenging, the created teaching materials should be able to facilitate students to think critically, creatively and independently, there are still some students whose score are below the minimum passing score.

A step to solve the above problem is to consider the characteristics and competencies of students, then it is necessary to develop an instructional media in the form of teaching materials. There are several types of teaching materials,e.g., printed books, modules, dictates, student worksheets and others. Student Worksheet is an activity sheet used to assist teachers to providing optimal learning. Student worksheet contains several indicators that should exist including the title / theme, objectives, time, instruction manuals, basic competencies and subject materials that must be achieved, informationandtasks related to the material. Based on the description, it is necessary to developsa student worksheet as a teaching material to facilitate the conveys of teaching materials.

Serene (2011: 520) states that the student worksheet is an instructional tool consisting of a series of questions and informationswhich is designed to guide students to understanding complex ideas systematically.

Meanwhile, according to Toman (2013: 178),the worksheets that developed based on a particular approach allow students to participate actively in the learning process, helps them to learn better, andimprove the students success. Therefore, by using student worksheets in learning activities, it can give a positive influence to students.It was emphasized in the literature that when they are well designed, worksheets can be a method of helping to shape expected behavioral changes in students (Proctor et.al., 1997).

However, the student worksheets that are available in schools in general is a conventional type of worksheet, which is not integrated with a particular model. In addition, the available student worksheetsarealso mostly not developed by the teacher themselves, which its contents are only a collection of questions without learning materials to support learning. In fact, the student worksheet should be developed by the teacher themselvesbecause teachers are the people who knows better about what is right for their students.

The 2013 curriculum using integrated thematic learning with a scientific approach. In accordance to these characteristics, it is necessary to select a learning model that is also scientific. One such learning model is theInquiry learning.

Kahn and O'Rourke (2005) describes an inquiry learning model as a broad umbrella term to describe an approach of learning that is driven by an inquiry process in their definition.

Coombs and Elden (2004) mphasizes the importance of the students knowledge that present in the process of finding. They define inquiry as a learning process that occurs when students develop an understanding of new information by relating it to previous knowledge in an organized and systematic way. In this context, inquirylearning isan exploration that based on the student's real life issuesusing process and tools of inquiry.

According to Rooneey (2012), inquiry learning model encourages students to think in a high level and show a positive attitude on the student learning activities.

Hansen and Buczynski (2013) shows thatwith the use of inquiry model, students are actively involved to think critically about the concepts of science, and students can make connections between what information they already knew and the new presented material.

Learning outcomeisa product of learning process that encompasses both cognitive and affective aspects (Lizzio et.al, 2002.). Cognitive outcome is refer to the development of professional knowledge and skill, whilenoncognitive outcome is focus on behavioral and individual values changes. Hamalik (2011:155) states thatlearning outcomeasan occurrence of behavioral changes in students, which are observed and measured in the form of knowledge, attitude and skill changes.

This research goal is to realize the development of teaching materials of thematic-basedstudent worksheet through Inquiry model,so it can improve the learning outcome of natural science for4th grader elementary school student,andalso to know the difference in the effectiveness of learning outcome of natural science between the one that usinglearning materials of thematic-based student worksheet through inquiry modelandthe one that not using student worksheeton4th grader students from Public Elementary Schooll of Pinang Jaya. 


\section{RESEARCH METHOD}

Research and development methods areabout to produce a student worksheet products, and test the effectiveness of these products. Borg and Gall (2003:569-575) states that development research is a process to develop and validate products that are used in education and learning.The procedure consists of ten steps. The following steps to produce the productinclude : early research and information gathering, planning, development of initial product, initial trial, product revision, field trial, product revision, operational field trial, final product revision, implementation.

The approach used in this research is a quantitative approach. The type of this research is research and development, namelystudent worksheet development on the theme of "Various Jobs"toimproving learning outcome of the 4th graderelementary school students. The population of this research is the Cluster 1 students from elementary school of Kemiling sub-district, andsamplein this research is the Public Elementary School 1 of Pinang Jaya withtotal 26 students of class IV A as experimentand 28 students of as IV B ascontrol.

The Instruments used to collect data in this study is a questionnaire of teacher's needs, validation sheets, pretest and postest questions.

The result of data validation was analyzed by descriptve quantitative method. Percentage of questionnaire data was obtained based on Likert scale calculation with the criteriasof very appropriate: score 4, quiteappropriate: score 3, less appropriate: score 1, not appropriate: score 1 .

The formula used in calculations to get a percentage is:

Percentage $(\%)=\frac{\text { Obtained score }}{\text { maximum score }} \times 100$

Interpretation criteria, a student worksheet is said to be appropriate if the content and presentation are suitable with the model of inquiry learning, andthe student worksheet suitablewith the student worksheet producing requirements if the result reaches $\geq 81 \%$, so that can be used in learning process.

Pretestandpostestare used tosee the improvement of learning outcome which is used to measure the effectiveness of the developed student worksheet.

The efectivenessof student worksheet were studiedwith the use of N-Gain. The increasingof score magnitude was calculated by the followingnormalized gain formula:

$$
g=\frac{\text { posttestscore }- \text { pretestscore }}{\text { maximumposssiblescore }- \text { pretestscore }}
$$

N-Gain Index is classifiedin table 1.

Table 1 Score of Normalized Gain Index

\begin{tabular}{|c|c|c|}
\hline Gain Index & Classification & Effectivity \\
\hline$(\mathrm{g}) \geq 0,70$ & High & Very effective \\
\hline $0,30 \leq(\mathrm{g}) \geq 0,70$ & Medium & Effective \\
\hline$(\mathrm{g})<0,30$ & Low & Less effective \\
\hline
\end{tabular}

\section{RESULTANDDICSUSSION}

\section{Research Outcomes}

The first hypothesis is the formation of thematic-based student worksheet through Inquiry learning model, so it can improve the learning outcomes of natural science for 4th grader elementary school students. The development of teaching material product in the form of student worksheet through Inquiry model with development procedure refers to Borg \& Gall development model which contains the following main steps of developmental research;

\section{Early Research and Information Gathering}

In this study, researcher started with a preliminary study, then analyzing the teachers' needs. Result from the analysisthen become the consideration of researcher to conduct research. Researcher using an observation technique. While do the observation, researcher identify the learning process in the classroom. Data from observation were analyzed and used as a consideration and base of student worksheet research.

Writer chooseElementary school 1 of Pinang Jaya, Kemiling Sub-district, Bandar Lampung City as the research place. The reason is because the school using 2013 curriculums and located inan easily accessible area and already accredited. This study begins with a preliminary study to see the present conditions ofthe schoolby analyzing student learning outcomes and teachers' needs.

\section{Planning}

The result of the planning step that had been done by the researcher was the student worksheet framework preparation, systematics determination, Planning of evaluation tool, and preparation of assessment instrument design. 


\section{Research of Initial Product Format}

This activity was done part by part accordingto the prepared student worksheet framework. The draft consists of cover (title page), preface, table of contents, Basic Competencies mapping, learning objectives, and student worksheet's instructions of use, Preparation of the student worksheetcontents was in accordance to the Inquiry step.

\section{Initial Trial}

The initial trialthat have been done by the experts aimto produced a product -in the form of student worksheet-that can be used by students. This internal trial consist of several tests from material expert and media expert. On validation process, the validator is lectors and teachers who gave advice or input for the student worksheet design improvement and suitability (revisi LKS I). Validators provide suggestions based on criteria of content, feasibility of content, suitability of thematic-based student worksheet through inquiry model, andsuitability ofstudent worksheetwiththe student worksheet producing requirements. Here is the recapitulation of score by validator :

Table 2Recapitulation of Validator Score

\begin{tabular}{ll}
\hline Validator & Score \\
\hline Material Expert & 91,66 \\
\hline Media Expert & 91,66 \\
\hline Teacherss & 91,37 \\
\hline
\end{tabular}

\section{Product Revision}

Product revisionwas implemented after product validation. Product valitaion was done bythree experts, i.e.,media expert, material expert, andclass teacher. Some of the advises and revisions arethe steps in the student worksheet shall be suitable with the Inquiry steps, make a references, improve contents to be more contextual, and change the imagesin the student worksheet learning activities.

\section{Main Field Trial}

The main field trialis the continuation of the experts test. Where the researcherspread the effectivity questionairesto 6 teachers of4th graderclass from 3 different schools. From the questionaire results, obtained this following data.

Table 3 Recapitulationof EffectivityQuestionnaire

\begin{tabular}{ll}
\hline School Name & Score \\
\hline Teacher ofClass IV A Elementary school I of Beringin Raya & 93,33 \\
\hline Teacher of Class IV B Elementary School I of Beringin Raya & 95,66 \\
\hline Teacher of Class IV A Elementary school 2 of Beringin Raya & 94,00 \\
\hline Teacher of Class IV B Elementary School 2 of Beringin Raya & 94,66 \\
\hline Teacher of Class IV A Elementary School I of Pinang Jaya & 96,00 \\
\hline Teacher of Class IV B Elementary I of Pinang Jaya & 96,66 \\
\hline
\end{tabular}

Based from the results above, then the developed student worksheet is feasible to go to the next stage of operational field trial, where the target isstudents from4th grade classes of Elementary school I Pinang Jaya.

\section{Product Revision}

This step was conducted after the main field trial, all comments and advisesfrom the previous main trial become a considerationfor the product improvements. Some improvements were done by fillingthe sectionimages that looks empty.

\section{Operational Field Trial}

Before the main learning activity begin, students are tested by a pre-test first. After thepre-testdone,studentsdo the learning activitieswith the student worksheet, and at the end of the learning,studentsdoa post-test. This was intended to see whether or not the changes/improvements in students learning outcomesbefore and after using the thematic-based student worksheet through the inquiry model on the theme of "Various Jobs"with sub-theme"Types of Job".

\section{Final Product Revision}

The final product revision process is based on the results of the hypotheses test and the findingsin the field when the product is tested. Based on the results of hypotheses test, its obtained that the student learning outcomes are increased. Furthermore, based on the result of consultations withmaterial expert andmedia expert, it was concluded that this thematic-based student worksheet through inquiry model is not revised and feasible to be implemented. 


\section{Second Hypotheses}

Student worksheet was effectiveto improve students learning outcome. Before the learning activity begin, students do a pre-test and after that do a post-test with the following results;

Tabel 4 Student learning Results On Field Trial

\begin{tabular}{lccc}
\hline \multirow{2}{*}{ School } & \multicolumn{2}{c}{ Average score } & \multirow{2}{*}{ increment \% } \\
\cline { 2 - 4 } & pretest & Postest & \\
\hline IV A & 55,77 & 73,65 & $17,88 \%$ \\
\hline IV B & 53,39 & 59,29 & $5,90 \%$ \\
\hline
\end{tabular}

The table above showed that, generally, there are differences and improvements in student learning outcomes after learning using thematic-based student worksheet through inquirymodel with the themeof "Various Jobs"sub-theme of "Types of Jobs".

The result of difference analysis usingindependent two samples t-test formula (independent) was obtained a valueof

$\mathrm{T}_{\text {value }}=7,149>\mathrm{t}_{\text {table }} 2,00$. There is a significant difference between the learning outcomes of the experimental and control classes.

Furthermore, to test the effectiveness of learning outcome, N-Gain Test was used, with the following results in the table 5 below.

Table 5 Result of $N$-GainPretest-Posttest after being calculated

\begin{tabular}{clc}
\hline No & Elementary School 1 of Pinang Jaya & Gain \\
\hline 1. & Class IV A $\quad$ (Experiment) & 0.39 \\
\hline 2. & Class IV B (Control) & 0,13 \\
\hline
\end{tabular}

From the table above, the average gain of the experiment class shows a result of 0,39 which meansthe normalized gain is in the medium classification, so the effectiveness level is effective.

The results showed that the thematic-based student worksheet through the developed inquiry model included in the effective criteria, this can be seen from the average score of the students whose using the thematic-based student worksheet through the inquiry model is 73.65 ,this is higher than the average score of the students who does not use thematic-based student worksheet through inquiry model, that is 59,29with the normalizedGainscore is 0,39 . This can be happened because the students usinga student worksheet that use the inquiry model steps, where in this model, learners are required to follow each steps in a systematic way.

So it can be concluded that the use of thematic-based student worksheet through the inquiry model on"Various Jobs" theme and "Types of Job" sub-themewas greatly helpthe students in the learning process, it can make learning activities more active and innovative, and students can find and solve their own problems by linking the learning materials with their own knowledges and experiencesin daily life.It will make it easier for students to absorb informations and process new materials, which will impact the students' learning outcomes to be better and improved. This student worksheet can also be used as an alternative teaching material for learning activities in classroom and as a self-learning material for students.

\section{Research Discussion}

Based on the research that had been conducted, The results of the study have shows the increased score in the pretest and post-test in both initial trial and field trial. Here are the results of research and the discussion of the thematic-based student worksheet through inquiry model research.

\section{Research on the development of thematic-based student worksheet through inquiry model}

Research on the development of thematic-based student worksheet through inquiry model in a thematic learning with theme of "Various Jobs"and sub-theme "Types of Job", can be described as follows. The research of thematicbased student worksheet through inquiry model was adapting the nine steps of R \& D by Borg \& Gall (2003 : 569 - 575), the first step is the initial research and information gathering, after the researcher know what problemshappened, the researcher does the planning to conduct research on the teaching materials of student worksheet that will be used by the students,so it can improve the students' learning outcome. Furthermore, the researcher preparing the research for initial product ofstudent worksheet, in this step, researcher pours the research pattern that will be conducted in thematic-based student worksheet through inquiry model. The next step is the initial trial,researchers does the validity test with three validators, this aims to validate the developed product whether it is suitable with study requirements or not, so it is worth to be trialled. The results of validity test can be described as follows.

Validation by Material Expert

Assessment from material expert includes the suitability of student worksheet with the content quality and suitability of student worksheet with inquiry. Some advises from material expert for product improvement are revising the steps inside the student worksheetso it moresuitable with the steps of inquiry, andcreate a references list in the student worksheet. 
Validation by Media Expert

Assessment from media expert includesthe requirements for making student worksheeti.e, didactic, construction and technical requirements. Some advises from media expert for product improvement are changing the contents of the student worksheet to be more contextual, and changing the display image on the worksheet's content to use the elementary school students' uniforms.

Validation by Classroom Teacher

Assessment from classroom teacher includes the suitability of student worksheet's contents, the suitability of thematic-based student worksheet through inquiry model, and the suitability of student worksheet with the producing requirements. In the validation process, there is no revision from classroom teacherbecause it was considered feasible to be used to obtains research data.

After conducting the validation test, researcher revising the product based on advises and comments from validators. The next step is the main field trial, at this stage, researcher tested the effectivity of student worksheet first.After that,researcher testedthe product on the experimental group, the obtained data states that students' learning outcomewere increased in pre-test and post-test score. Then, researcher did a revision to perfecting the product.

The last step is the operational field trial.At this step, itwas obtaineddata of students' learning outcome that shows the improvement in pre-test and post-test scores,so it can be concluded that the developed product was effective in a thematic learning and also improve the students' learning outcomes. The form of the thematic-based student worksheet product through developed inquiry model can be described brieflyin the following : the title page (cover), on cover page consist of title, author's name, student worksheet's identity, supporting image, user target, student worksheet statement, and background.Preface, a form of expression from the author's mind.

Student learning activities that contained in thematic-based student worksheet through inquiry model adapting six components from the opinion of Sanjaya (2006: 201) i.e., orientation, formulate problems, formulate hypotheses, collect data, hypotheses test and formulate conclusions. Those six components were applied in the student learning activities through this research of thematic-based student worksheet through inquiry modelwhich make students' activities more active, so it canimprove students' learning outcome. According to the opinion of constructivism psychologist,Sukardjo (2013: 54), this learning theory emphasizes that individuals gain knowledge from the process of knowledge formation by linking apreviously possessed knowledges with the current knowledgesand was done independently bythe individual. This thematic-based student worksheet through inquiry model is considered very suitable to use, because in the learning steps, learners are directly involved to gain their understanding through systematic inquiry steps. This is similar to Suhana's opinion (2012:77), inquiry methodis a serie of learning activities that maximallyinvolve all the students'componentsto search and investigate systematically, critically and logically, so they can find their own knowledges, attitudes and skills as a form of change.

So, it can be concluded that the use of thematic-based student worksheet through the inquiry model on the theme 4 and sub-theme 1 is very helpful for students in the learning process, make learning activities more active and innovative, help the students to find and solve their own problems by linking the materials with the knowledges and experiencesthey have from daily life, it will make students easierto absorb informations and process new materials, which will impactson the improvement of students' learning outcomes. And this student worksheet can be used by teachers as an alternative teaching materials in the learning process from classroom and as a selflearning materials for students (Lee, 2014:101)

\section{Effectiveness of thematic-based student worksheet through inquiry model}

The effectiveness of thematic-based student worksheet through inquiry model were seen from the comparison of pre-test and post-test outcomes between the experimental class and the control class. The result of analysis by using t-test shows that the learning scores after following the lesson using thematic-based student worksheet through inquiry model is higher than before using thematic-based student worksheet through inquiry model.

One of the learning theories that become the reference of this thematic-based student worksheet through inquiry model research is the constructivism learning theory,where according to this theory, learning is not only related to a memorizing course material, but learning is also a meaningful experience for students. Students find information by themselves and transform complex information, check for new information and revise it if the rules are not appropriate.

The learning process should be designed and managed in such a way to encourage students to organize their own experiences into a meaningful knowledge. So, in the view of constructivism, students' role are very important to be able to build constructivis habits of mind.In order tobuild a thinking habit to students, it needs a learning freedom and attitudes.

Vann and Harrey (2005: 115) stated that the atmosphere of inquiry learning that built into a school context is closely linked to the self-directed learning in a classroom performance.

Aykol \& Garrison (2011) stated that learning with inquiry model provides a deep and meaningful learning 
experience.

According Sanjaya (2006: 208) the advantage of inquiry method is: the inquiry method is a method that emphasizes the research of cognitive, affective and psychomotor aspects in a balanced way,so the learning process will be more meaningful. Inquiry method provides space for students to learn according to their learning style. Inquiry method is a model that considered suitable for the development of modern learning psychology, which considers learning process asa process of behavior change. Another advantage of this learning method is to serve the needs of students who have above average level. That means, students who have good learning ability will not be late from students who have weaker learning ability.

The effectiveness of student worksheet teaching materials is corroborated by Yildirim's opinion (2011: 52) that states the activity sheet may affect the student's accomplishments.Based on these theories, in this research, the effectiveness of learning was measured through student learning outcomes, by looking at the levelof learning outcomes that obtained before and after using thematic-based student worksheet through inquiry model. The effectiveness of learning can be seen from the incrementof average scores before and after using thematic-based student worksheet through inquiry model.Furthermore, the normalized gain score of students' learning outcomesthat using thematic-basedstudent worksheetwith inquiry model was categorized into the medium category.

Utami (2016) states that student worksheet can attract students' responses to sound their opinions, asking questions and discussions in a group.

Celikler (2011: 56) also states thatthe experimental group students that learn by using activity sheets were more successful than the control group students that learn by traditional teaching methods, and a developed student worksheet influences on their learning outcomes.

The results showed that this developed thematic-basedstudent worksheet through inquiry model were categorizedin the Effective criteria, as seen from the average score of students who using the thematic-based student worksheet through inquiry model is 73,65 which is higher than the average score of students who did not use thematic based worksheet through inquiry model with 59.29, with a normalized Gain score of 0.39 . This can be happened because students usingstudent worksheet with inquiry model steps, where in this model, learners are required to follow each steps systematically. Lederman, Judith, andAntink (2013: 17) reveals that inquiry is askill development for processing, classifying, predicting, measuring, questioning, interpreting and analyzing data.

\section{CONCLUSION / CLOSING}

Based on the research and discussion results above, it can be concluded as follows.

The thematic-based student worksheet product with inquiry model was made through validations of material expert, design expert, and practitioners, and based onthe test results to students as users, it can support the learning process quite well. The produced student worksheet product in this study was effective to improve the student learning outcomes, and significantly improving the learning resultswhich were studied from the differences of pre-test and post-test scores, and the scoreresults were significantly different betweenthe experimental class andthe control classon4th graderstudentsfromPublic Elementary School I of Pinang Jaya.

\section{REFERENCES}

Aykol, Zehra \& Garrison, D. Randy. 2011. Understanding Cognitive Presence in an Online and Blended Community of inquiry: Assessing Outcomes and Processes for Deep Approaches to Learning. British Journal of Educational Technology. Vol. 42, No 2, 233-250.

Borg, D. Walter, Joyce P. Gall and Meredith D. Gall. 2003. Educational Research An Introduction. Boston: Perason Education, Inc (569-595)

Celikler, Dilek.2011. The effect of worksheet developed for the subject of chemical compounds on student achievement dan permanent learning.Educational research association. The International Journal of Research in Teacher Education. Volume 1. No 1, 42-51

Coombs, G and Elden, M. (2004). Introduction to the Special Issue: Problem-Based Learning as Social Inquiry: PBL and Management Education. Journal of Management Education. 52(3)

Hamalik, Oemar. 2011. Proses Belajar Mengajar. PT Bumi Aksara. Jakarta.

Hansen \& Buczynski. 2013. The Teaching of Inquiry-based Science in Elementary Classrooms: A Bi-national Comparative Reflection of US and Lithuanian Practices. International Journal of Higher Education. Vol. 2, No. 3, 41-53.

Kahn, P. and O'Rourke, K. (2005). Understanding Enquiry-Based Learning (EBL) In Barrett, T., Mac Labhrainn, I. and Fallon, H. (Eds.), Handbook of enquiry and problem-based learning: Irish case studies and international perspectives.

Galway: Centre for Excellence in Learning and Teaching, National University of Ireland.

Lederman, Norman G.,Judith S Lederrman, Allison Antink. 2013. Nature of Sience and Sciencetific Inquiry as Contexts for the Learning of Science and Achievement of Scientific Literac. International Journal of 
Education in Mathematics, Science and Technology. Vol 9. No 4. www.ijemst.com.

Lee, Che-Di.2014. Worksheet Usage, Reading Achievement, Slasses' Lack Of Readiness, And Science Achievement: A Cross-Country Comparison. International Journal Of Education In Mathematics, Science And Tecnology. Volume 2, No. 2, 96-106.

Lizzio, A., Wilson, K., \& Simons, R. (2002). University students' perceptions of the learning environment and academic outcomes: implications for theory and practice. Studies in Higher Education, 27(1), 27-52.

Proctor, A., Entwistle, M., Judge, B. \& McKenzie-Murdoch, S. (1997). Learning to teach in the primary classroom, New York: Routledge.

Rooney, Caitriona. 2012. How am I using inquiry-based learning to improve my practice and to encourage higher order thinking among my students of mathematics?. Educational Journal of Living Theories. Vol. 5, No.2, 99-127.

Sanjaya, Wina. 2006. Strategi Pembelajaran Berorientasi Standar Proses Pendidik. Kencana. Jakarta.

Serene S. 2011. Effect of worksheet scaffolds on student learning in problem-based learning. Adv in Health Science Education Journal. Vol 16, 517-528.

Suhana, Cucu. 2012. Konsep Strategi Pembelajaran. Refika Aditama : Bandung.

Sukardjo. 2013. Landasan Pendidikan. Rajawali Pers : Jakarta.

Toman, Ufuk. 2013. Extended Worksheet Developed According To 5e Model Based On Constructivist Learning Approach. International Journal on New Trends in Education and Their Implication. Volume 4, 173 - 183.

Utami, Wiwik S. 2016. The Effectiveness of Geography Student Woerksheet to Develop Learning Experience for High School Student. Journal of Education and Learning. Vol 5, No.3, 315-321.

Van Deur, Penny dan Rosalin Murray - Harrey. 2005. The inquiry nature of primary schoools and student's selfdirected learning knowledge. International Education Journal. Vol. 14, No.6

Yildirim, Nagihan. 2011. The Effect Of The Worksheets On Students' Achievement In Chemical Equilibrium. Journal of Turkish Science Education. Volume 8, 44-58. 